\title{
REKONSTRUKSI MATERI DAKWAH UNTUK PEMBERDAYAAN PEREMPUAN: PERSPEKTIF TEOLOGI FEMINISME
}

\author{
Masthuriyah Sa'dan \\ Universitas Islam Negeri Sunan Kalijaga Yogyakarta \\ masthuriyah.sadan@gmail.com
}

\begin{abstract}
Abstrak: Dakwah adalah sebuah kegiatan untuk menyampaikan pesan-pesan agama yang dilakukan oleh seorang da'i. Kegiatan dakwah gencar di laksanakan, akan tetapi dakwah hanya bersifat ukhrawi-oriented, dan bukan sosial-kontekstual. Akibatnya dakwah belum mampu menyelesaikan persoalan ummat yang terkait dengan isu-isu perempuan. Ironisnya, dakwah yang disampikan oleh para da'i justru menambah dan memperkuat beban perempuan dalam kerangkeng agama. Akibatnya perempuan terpasung dalam otoritas teks yang di dalangi oleh laki-laki. Oleh sebab itu, sebenarnya ada yang perlu dirubah dalam dakwah. Salah satunya adalah perubahan konten materi dakwah. Rekonstruksi materi dakwah dilakukan dengan menggunakan analisa teologi feminis dalam hal ini feminis muslim
\end{abstract}

Kata Kunci: dakwah, rekonstruksi materi, feminisme

\section{Pendahuluan}

Dakwah merupakan kewajiban bagi setiap muslim baik laki-laki maupun perempuan. Tugas kewajiban dakwah dalam lintasan sejarah Islam merupakan tugas kewajiban dari Allah yang tertulis dalam Al-Qur'an,

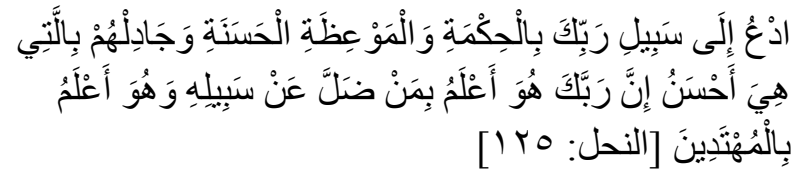

"Serulah (manusia) kepada jalan Tuhan-mu dengan hikmah dan pelajaran yang baik dan bantahlah mereka dengan cara yang baik. Sesungguhnya Tuhanmu Dialah yang lebih mengetahui tentang siapa yang tersesat dari jalanNya dan Dialah yang lebih mengetahui orangorang yang mendapat petunjuk." (QS. alNahl:125)

Selain perintah Allah, Nabi Muhammad SAW juga menyuruh kepada umatnya untuk berdakwah, sebagaimana sabda Nabi yang berbunyi,

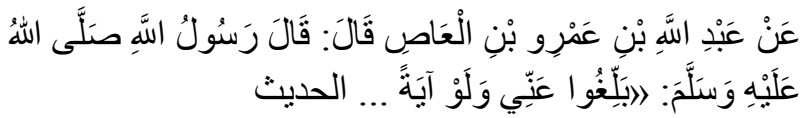

"Dari 'Abdullah bin 'Amr bin 'Ash, dia berkata: Rasulullah saw. bersabda: Sampaikanlah (apa yang kalian dapat) dariku walau hanya satu ayat ..." (Abu Muhammad 'Abdullah bin 'Abd alRahman al-Darimi, Sunan al-Darimi, Dar alMughni, Saudi, Juz 1).

Hadist tersebut mengindikasikan makna bahwa kegiatan dakwah boleh dan harus dilakukan oleh siapa saja yang memiliki rasa keterpanggilan untuk menyebarkan nilai-nilai dan ajaran Islam. Landasan kegiatan inilah yang kemudian dijadikan sebagai pijakan dasar umat Islam terhadap keberlangsungan Islam sejak masa Nabi Muhammad SAW hingga era kini. Dakwah Islam merupakan sebuah upaya agar Islam diserukan, disebarluaskan dan disampaikan kepada orang lain. Penyebaran Islam tersebut merupakan komitmen seorang muslim atas keislamannya. 
Sejarah mencatat, bahwa Islam tidak terlepas dari dakwah. Bahkan, Islam dianggap sebagai agama dakwah. Dalam artian agama yang didalamnya terdapat usaha untuk menyebar luaskan kebenaran dan mengajak orang-orang untuk selalu dalam koridor Islam (Arnold, 1981). Dakwah sebagai aktivitas menyampaikan pesan-pesan moral dalam rangka memberikan pencerahan dan pemberdayaan dalam berbagai aspek kehidupan, baik sosial, budaya, ekonomi, politik dan lain sebagainya. Karena itu, esensi dari tujuan dakwah adalah bagaimana menciptakan suatu kondisi umat Islam menjadi lebih baik. Menciptakan suatu kondisi yang lebih baik tersebut mencakup pada berbagai lini kehidupan. Baik pemindahan dari situasi kebodohan menjadi situasi umat yang melek keilmuan dan tekhnologi. Disamping itu, dakwah juga bisa bermakna sebagai sebuah upaya untuk menciptakan suatu kehidupan yang sejahtera, aman dan damai dengan mengembangkan kreativitas individu dan masyarakat. Disini, dakwah dapat dikatakan dengan bahasa lain sebagai proses pemberdayaan (Munir, dkk., 2006). Yakni pemberdayaan pada diri individu, keluarga, kelompok dan masyarakat di sekitarnya.

Perkembangan kemajuan ilmu pengetahuan tekhnologi dan informasi yang ditandai dengan perubahan yang sangat cepat menimbulkan pergeseran nilai-nilai kehidupan manusia dan agama. Kondisi yang demikian, dengan spontan membawa implikasi terhadap pelaksanaan dakwah yakni timbulnya problem dakwah. Al-Bayanuni mengidentifikasi problem dakwah ke dalam dua faktor: pertama, internal yakni sempitnya wawasan dan lemahnya pelaksanaan dakwah di kalangan umat muslim. Kedua, faktor eksternal terkait dengan upayaupaya dari kelompok tertentu yang memusuhi umat muslim disamping dari modernisasi dan globalisasi yang mengancam nilai-nilai spiritual Islam (Alawiyah, 1992).
Pelaksanaan pembangunan nasional selama ini hanya lebih mengedepankan pada pembangunan fisik. Sedangkan pembangunan mental, moral dan spiritual kurang mendapat porsi perhatian. Hal yang demikian, berdampakn pada kehidupan moral spiritual umat manusia. Oleh karena itu, diperlukan sebuah upaya bersama untuk bersama-sama mengadakan pembangunan yang tidak hanya berorientasi pada pembngunan fisik semata melainkan juga pada pembangunan manusia seutuhnya, yakni pembangunan manusia yang seimbang antara fisik, mental dan spiritual. Pada titik inilah, kegiatan dakwah menjadi sebuah kebutuhan.

Salah satu aspek penting yang harus diberdayakan dalam kegiatan dakwah adalah pemberdayaan terhadap eksistensi perempuan. Hal itu karena perempuan rentan terhadap diskriminasi baik itu oleh struktur budaya masyarakat maupun agama. Agama Islam dalam hal ini teks ayat Al-Qur' an maupun hadist lebih banyak streotipe dan menempatkan perempuan hanya pada ranah domestik an sich. Akibatnya, perempuan terpasung oleh teks-teks suci dari alQur'an dan hadist atas nama agama. Padahal, teks-teks tersebut telah dimainkan oleh budaya patriarkhi yang hanya untung di pihak laki-laki dan timbang di pihak perempuan. Kenyataan yang demikian menurut Muhsin (1994), menunjukkan bahwa laki-laki menganggap perempuan sebagai inferior, sementara laki-laki sebagai superior. Sehingga menyebabkan perempuan dan laki-laki tidak dapat setara dalam hal apapun.

Jika mengaitkan antara dakwah dan perempuan. Telah banyak dilakukan dakwah bagi komunitas perempuan, dan bahkan penceramah agamapun dilakukan oleh seorang perempuan yang disebut dengan muballighah atau ustadzah atau nyai. Akan tetapi, isi ceramah mereka yang seharusnya untuk mengangkat eksistensi perempuan, memperjuangkan bentukbentuk pemiskinan terhadap perempuan dan 


\section{6-45 | HARKAT: Media Komunikasi Islam Tentang Gender dan Anak, 12 (1), 2016}

menyampaikan pesan-pesan agama dalam ayat alQur'an dan hadist yang adil gender menjadi berbanding terbalik. Mereka (para muballighah) justru mendukung pemasungan, pemiskinan, marginalisasi, diskriminasi dan streotipe perempuan atas nama teks-teks agama. Ironisnya, isi materi dakwah yang disampaikan justru memperkuat fondasi patriarkhi dan mengikat kuat perempuan dalam kerangkeng penjara rumah dengan iming-iming perempuan sholehah, istri sholehah dan balasan surga.

Disamping itu, perempuan rentan dan resisten mengalami berbagai persoalan. Terjadinya pelecehan seksual di tempat umum, perkawinan anak di bawah umur (chield of marriage), perdagangan perempuan dan anak (trafficking), prostitusi online, angka kematian ibu dan bayi yang semakin meningkat, tertutupnya peluang bagi anak perempuan untuk menempuh pendidikan tinggi dan pemiskinan terhadap perempuan seringkali terjadi di depan mata. Persoalan tersebut tidak hanya persoalan di wilayah regional dan nasional. Bahkan level internasionalpun, pemberdayaan dan perlindungan terhadap perempuan acapkali diabaikan. Perlindungan dan pemberdayaan terhadap perempuan pada level problem demikian menuntut berbagai elemen dan pihak untuk turut serta menyelesaikan problem kemanusiaan yang tidak kunjung selesai tersebut. Maka pada tataran inilah, da'i berperan dan berpeluang untuk turut serta membantu memperjuangkan hak-hak asasi perempuan. Hubungan antar manusia dalam Islam didasarkan atas prinsip-prinsip keadilan (al'adlu), kesetaran (al-musawa), persaudaraan (alukhuwah al-Islamiyah) dan kemaslahatan bersama. Jangan sampai adagium Islam yang mengatakan bahwa Islam shahih li kulli zaman wa makan tidak hanya menjadi adagium kosong dan slogan tanpa makna. Melainkan dapat terlihat dan dirasakan oleh umat manusia seluruhnya sebagaimana yang selalu digaungkan selama ini bahwa Islam rahmatan lil 'alamien".
Dengan berdasar pada fenomena demikian, maka dibutuhkan seorang da'i yang tidak hanya menyampaikan materi dakwah 'ubudiyah (ibadah) dan ukhrawiyah (surga dan neraka) yang hanya menciptakan kesalehan individual. Melainkan kesalehan sosial juga harus ditekankan. Seorang da'i dituntut untuk memberikan solusi alternatif atas persoalan umat, dalam hal ini persoalan perempuan, dengan cara memberikan landasan filosofis, arah, dorongan dan pedoman pada tingkat realitas yang lebih real (Ahmad, 1985). Atas dasar kebutuhan itulah, tulisan ini ingin mengkaji suatu model dakwah untuk pemberdayaan perempuan. Model dakwah tersebut dengan cara merekonstruksi materi dakwah yang selama ini gencar dilakukan oleh da'i. Rekonstuksi materi dakwah tersebut adalah materi dakwah yang bersumber dari teks-teks agama yang mengindikasikan kekerasan terhadap perempuan. Rekonstruksi materi dakwah tersebut dengan menggunakan analisis teologi feminisme.

Rekonstruksi yang dimaksud adalah rekonstruksi materi dakwah dari yang mulanya ukhrawi-oriented menjadi sosial-kontekstual, dari yang mulanya rujukan dan dalil ceramah yang digunakan adalah teks-teks tafsir ayat dan hadist yang misoginis menjadi ayat dan hadist yang humanies dan adil gender. Pergeseran orientasi ini tidak harus menghapus materi dan dalil-dalil teks yang dikutip, melainkan dengan pergeseran orientasi tersebut justru kekuatan normatif agama dipadukan dengan realitas yang terjadi di masyarakat dan menjadi kebutuhan masyarakat, sehingga agama menjadi terasa hidup dan menghidupkan "shahih li kulli zaman wa makan".

\section{Hakikat Dakwah}

Secara etimologis, ungkapan kata dakwah berasal dari bahasa Arab, yakni da'a, yad,u, da'wan, du'a. Yang artinya adalah mengajak, menyeru, memanggil, seruan, permohonan dan 
permintaan (Majma, 1972). Istilah dakwah dalam al-Qur'an diungkapkan dalam bentuk fi'il maupun masdhar sebanyak lebih dari seratus kata. Dalam Al-Qur'an, dakwah dengan arti mengajak disebut sebanyak 46 kali. 39 kali ajakan kepada Islam dan kebaikan. Dan 7 kali mengajak ke neraka atau kejahatan.

Disamping itu ada banyak sekali ayat-ayat yang menjelaskan istilah dakwah dalam konteks yang berbeda (Dermawan, dkk., 2002). Dengan demikian, terdapat dua pengertian dakwah. Pertama, makna umum dakwah ialah suatu ilmu pengetahuan yang berisi cara-cara tuntunantuntunan, bagaimana seharusnya menarik perhatian manusia untuk menganut, menyetujui, dan melaksanakan. Kedua, makna Islam mengenai dakwah adalah mengajak manusia dengan cara bijaksana kepada jalan yang benar sesuai dengan perintah Allah untuk kemaslahatan dan kebahagiaan di dunia dan akhirat (Umar, 1971). Pada hakikatnya, tujuan dari dakwah Islam adalah terwujudnya tatanan masyarakat yang di ridhoi oleh Allah SWT, sebuah masyarakat yang selalu dalam garis iman dan Islam dengan berdasarkan pada ajaran pokok Islam yakni aqidah, syari'ah dan akhlak (Puteh, 2000).

Dalam rangka mewujudkan tatanan masyarakat yang demikian, dakwah selayaknya mengemban empat konsep. Pertama, yad'una ila al-khairi, adalah menyeru umat manusia untuk menerima dan mengamalkan ajaran Islam yang menjadi sumber kebaikan dan kebenaran yang hakiki dalam seluruh aspek kehidupan. Kedua, amar ma'ruf; memerintahkan manusia untuk berbuat kebajikan yang di ridhai oleh Allah untuk measlahatan bersama, baik untuk individu maupun untuk masyarakat. Ketiga, nahyul munkar, menghalangi diri dari perbuatan munkar yang dapat membawa kerugian dan bencana terhadap masyarakat. Keempat, taghyirul munkar adalah merubah setiap bentuk kemungkaran yang terdapat dalam kehidupan manusia sehingga kemungkaran tersebut berubah menjadi kebaikan (Supena, 2013). Dari berbagai konsep yang demikian, dakwah hakikatnya adalah merubah masyarakat dari kondisi yang tidak baik menjadi kondisi yang lebih baik.

$\begin{array}{ccrr}\text { Pada } & \text { prinsipnya, dakwah merupakan } \\ \text { proses } & \text { komunikasi } & \text { dalam } & \text { rangka }\end{array}$
mengembangkan ajaran Islam, dalam arti mengajak orang untuk menganut ajaran Islam. Pada istilah "mengajak" tersebut, maka terkandung makna mempengaruhi orang lain agar orang lain mau dan mampu mengubah sikap, sifat, pendapat dan prilaku sesuai dengan apa yang dikehendaki oleh orang yang mengajaknya (Suhandang, 2013). Dalam prinsip dakwah sebagai komunikasi, apabila terdapat dua orang berkomunikasi, akan terjadi proses saling mempengaruhi, sebab para da'i akan selalu berusaha memenangkan pengaruhnya, dan sebaliknya atas persepsinya, para mad'u pun akan mempertahankan sifat, sikap, pendapat dan perilaku. Proses yang demikian telah digambarkan oleh Allah dalam al-Qur'an QS. AlBaqarah:170. Agar proses mempengaruhi itu berjalan efektif maka terdapat tiga langkah pendekatan yang harus dilakukan. Pertama, mencari tahu situasi dimana komunikasi itu berlangsung. Kedua, mencari tahu status pribadi komunikan (mad'u). Ketiga, mengetahu ikatan norma-norma kelompok komunikan (Schramm, 1965).

\section{Konsep Pemberdayaan Perempuan}

Secara nasional, pemberdayaan perempuan dapat diartikan sebuah upaya untuk meningkatkan kemampuan perempuan untuk memperoleh akses kontrol terhadap sumber daya ekonomi, politik, sosial budaya agar tiap-tiap individu dapat mengatur diri dan meningkatkan rasa percaya diri sehingga mampu berperan dan berpartisipati aktif dalam memecahkan masalah sehingga mampu membangun kemampuan dan konsep diri (PP Rippnas, 2000-2004). 


\section{8-45 | HARKAT: Media Komunikasi Islam Tentang Gender dan Anak, 12 (1), 2016}

Sementara Tan memberikan arti berbeda, menurut Tan pemberdayaan perempuan adalah keinginan untuk melakukan sharing kekuasaan dalam posisi setara (equal), representatif serta partisipatif dalam pengambilan keputusan yang menyangkut kehidupan berkeluarga, bermasyarakat, bernegara dan berbangsa (Tan, 1997). Lebih lanjut, Priyono berpendapat bahwa inti dari proses pemberdayaan perempuan adalah memberikan pemahaman akan posisi subordinasi yang mereka temukan dalam kehidupan seharihari, dimana dalam proses ini tercipta kesadaran pada perempuan akan kondisi mereka yang tidak menguntungkan dan kemudian berpaartisipasi aktif dalam struktur pembangunan untuk merealisasi hak-hak sosial politik dan ekonomi (Priyono, 1996).

Melakukan perubahan sosial pada kultur masyarakat yang telah mapan, bukanlah hal yang sulit. Apalagi dalam hal ini adalah pemberdayaan pada perempuan. Hal itu karena dalam proses perubahan harus difokuskan pada pertumbuhan individu perempuan dan lingkungannya untuk mengidentifikasi dan menghormati nilai-nilai dan hak-hak perempuan. Maka kata kuncu keberhasilan tersebut adalah menciptakan dan menyediakan sistem yang mendukung tujuan pemberdayaan perempuan. Strategi pemberdayaan perempuan dapat dilakukan melalui pendekatan indifidual, kelompok atau kolektif dengan saling memberdayakan sesama perempuan dalam suatu kelompok. Upaya pemberdayaan tersebut meliputi usaha menyadarkan, mendukung, mendorong dan membantu potensi yang terdapat pada diri individu, sehingga menjadi manusia yang mandiri dan berkepribadian (Priyono, 1996).

Dalam upaya pemberdayaan masyarakat Kartasasmita mengemukakan tiga hal. Pertama, menciptakan suasana yang memungkinkan potensi masyarakat berkembang, bahwa setiap masyarakat memiliki potensi yang dapat dikembangkan dan tidak ada masyarakat yang sama sekali tanpa adanya daya. Fokus pemberdayaan yang dimaksud disini adalah pemberdayaan pada membangun daya tersebut, dengan mendorong, memotivasi dan membangkitkan kesadaran akan potensi yang dimilikinya serta berupaya untuk mengembangkannya. Kedua, memperkuat potensi atau daya yang dimiliki oleh masyarakat (empowerting). Memperkuat tersebut dengan cara memberi masukan (input) dan pembukaan akses kepada berbagai peluang (oppurtinies) yang akan membuat masyarakat menjadi semakin berdaya. Ketiga, pemberdayaan mengandung pula arti melindungi. Dengan demikian, pemberdayaan perempuan melalui dakwah dapat diartikan sebagai sebuah usaha untuk menyadarkan, mendukung, mendorong, membantu dan melindungi hak-hak perempuan dari berbagai faktor yang merampas hak-hak perempuan atas nama agama. Melalui dakwah dengan pemberdayaan perempuan inilah, seorang da'i dapat membangun eksistensi perempuan dengan cara mereduksi dan merekonstruksi teks-teks agama yang misoginis dan patriarkhis.

\section{Teologi Feminis Sebuah Analisis}

Teologi feminis bersumber dari madzhab teologi pembebasan (liberation theology) yang dikembangkan pertama kali oleh James Cone (1960-an). Teologi pembebasan mulanya diaplikasikan oleh buruh tani di Amerika Latin dan beberapa kelompok yang dianggap tertindas. Pola relasi materialistik dan ekonomi menurut Marx adalah pondasi masyarakat yang mendasari segala hukum, moral, agama dan institusi politik kemasyarakatan. Hal yang demikian oleh Marx disebut dengan superstruktural (superstructure). Mengutip analogi dan bahasa Megawangi (1996), ibarat sebuah bangunan, superstruktural adalah atap masyarakat. Yang menggambarkan sebuah ideologi, agama dan norma-norma kemasyarakatan. Atap dari bangunan tersebut 
sangatlah bergantung dari tiang-tiang sebagai fondasi bangunan. Tiang-tiang penyangga inilah yang disebut dengan basis relasi sosial. Karenanya, superstruktural dapat dimanipulasi dan diubah-ubah sesuai dengan kepentingan. Jika Marx berpandangan bahwa agama hanya murni dipakai oleh kelas penguasa untuk melegitimasi kekuasaanya. Maka paham teologi pembebasan adalah menggunakan agama sebagai alat untuk membebaskan golongan yang selama ini dianggap tertindas.

Teologi pembebasan yang diterapkan pada perempuan yang dianggap sebagai kelas tertindas inilah yang disebut dengan teologi feminis (feminist theology). Teologi feminis berkembang pada berbagai agama seperti Kristen, Yahudi dan Islam (Megawangi, 1996). Feminis teologi berpandangan bahwa agama-agama seringkali ditafsirkan dengan menggunakan ideologi patriarkhi sehingga perempuan tersudutkan. Isu-isu yang seringkali di perdebatkan adalah tentang status penciptaan Hawa yang dari tulang rusuk Adam, bolehnya perempuan menjadi pemimpin, dan lain sebagainya. Akibat dari interpretasi teks tersebut, feminist teologi berkesimpulan bahwa seolaholah perempuan adalah makhluk kedua (secondary creation) setelah laki-laki.

\section{Berdakwah Untuk Pemberdayaan \\ Perempuan}

Seiring dengan perkembangan zaman, masyarakat mulai mengalami perubahan baik dari cara pandangan (world view), gaya hidup (live style) maupun nilai kehidupan sehari-hari. Agar pesan dakwah tetap eksis di zaman yang mengalami perubahan dan perkembangan dengan dinamika sosial masyarakatnya, maka paradigma, strategi dan aksi dakwah juga harus mengalami inovasi. Perubahan tersebut adalah dengan cara merubah konsepsi dakwah dari yang mulanya dakwah konvensional (baik metode maupun kontennya) yang cenderung normatif menuju dakwah yang bersifat transformatif dan mencerahkan. Semangat perubahan tersebut ternyata tidak hanya karena tuntutan zaman yang berubah melainkan semangat perubahan yang sejak beberapa abad yang silam di perintah oleh Allah.

Menurut Alawaiyah (1997), dakwah yang dilakukan oleh seorang muballigh merupakan suatu bentuk kebebasan berpikir untuk mengemukakan pendapat sebagai salah satu hak asasi dan sebagai salah satu kaidah agama. Jika dikorelasikan dengan konsep feminisme Islam yang berusaha memperjuangkan dan membebaskan perempuan-perempuan muslimah dari kungkungan dogmatisme agama sebagai akibat dari interpretasi teks yang misoginis. Maka titik temu keduanya adalah pada risalah atau ajakan sampainya pesan-pesan Tuhan yang menjunjung hak asasi perempuan kepada semua umat manusia sehingga nantinya terwujud sebuah masyarakat yang lebih baik (khairo ummah).

Dalam dakwah Islam terdapat beberapa unsur yang harus dipenuhi dalam kegiatan dakwah. Unsur dakwah ini merupakan komponen-komponen yang terdapat dalam setiap kegiatan dakwah Islam. Unsur-unsur tersebut meliputi:

\section{Da’i (Pelaku dakwah)}

Da'i adalah orang yang melaksanakan kegiatan dakwah yang dilaksanakan dengan lisan, tulisan maupun dengan perbuatan yang dilakukan baik secara individu, kelompok atau melalui organisasi atau lembaga. Biasanya para da'i disebut dengan muballigh. Akan tetapi kata muballigh ini kadangkala diartikan dengan sempit yakni orang-orang yang menyampaikan risalah agama melalui lisan seperti ceramah agama, khatib dan lain sebagainya. Padahal dalam Islam, siapa saja diperbolehkan menjadi da’i. Dengan demikian, maka umat Islam 
diharuskan untuk mengetahui akidah, syari'ah dan akhlak (Munir, 2006). Penekanan Allah mengenai umat Islam untuk berdakwah adalah sebagaimana dalam firmanNya QS. Attaubah:122.

Karena menjadi da'i diperbolehkan kepada siapa saja bagi umat muslim untuk menyampaikan pesan-pesan agama dalam hal ini pesan-pesan agama mengenai kebenaran ajaran Islam tentang keadilan gender. Maka selayaknyalah, seorang da'i memiliki kesadaran dalam dirinya, kesadaran tersebut adalah kesadaran gender, bahwa perempuan adalah "kelas" yang tidak diuntungkan. Proses penyadaran tersebut adalah usaha untuk membangkitkan rasa emosi (emotional arousal) perempuan agar mereka bangkit untuk mau merubah kondisinya. Jika seorang da'i memiliki kesadaran gender dalam dirinya, maka ia akan menyampaikan pesan-pesan Tuhan tanpa adanya prejudice, streotipe, diskriminatif dan marginalisasi kepada perempuan atas nama agama.

\section{Mad'u (obyek dakwah)}

Obyek dakwah adalah manusia penerima dakwah, baik sebagai individu, maupun kelompok. Dalam proses dakwah antara da'i dengan mad'u ada yang namanya komunikasi. Disini mad'u diartikan sebagai sasaran dakwah. Menurut Suhandang, Mad'u pada dasarnya adalah komunikasi dari kegiatan dakwah itu sendiri (Suhandang, 2013). Pada tataran dakwah, obyek dakwah tidak terbatas hanya kepada umat Islam saja. Melainkan kepada seluruh umat manusia.

Jika obyek dakwah yang universal kepada seluruh umat manusia dikaitkan dengan konsep feminisme. Maka penyampaikan pesan-pesan Tuhan yang adil gender tidak hanya terbatas kepada umat manusia yang berjenis kelamin perempuan, melainkan kepada seluruh umat manusia baik laki-laki maupun perempuan. Hal itu dengan tujuan, agar objek dakwah (laki-laki dan perempuan) memiliki pengetahuan bahwa perempuan selama berabad-abad lamanya terpasung oleh otoritas teks yang timpang sebelah. Dengan adanya pengetahuan gender yang demikian, maka lambat laun obyek dakwah (laki-laki dan perempuan) akan memiliki kesadaran gender dalam dirinya. Kesadaran tersebut merupakan konsekuansi dari pengetahuan dan pengalaman individu secara personal maupun kelompok.

\section{Maddah (materi dakwah)}

Materi dakwah selama ini terkait dengan isi pesan atau materi yang disampaikan da'i kepada mad'u. Dalam hal ini, yang menjadi sumber utama dalam materi adalah ajaran agama Islam itu sendiri. Secara umum materi dakwah Islam dapat diklasifikasi ke dalam empat pokok yakni: akidah, syari'ah, muamalah dan akhlak.

Agar materi dakwah dapat berjalan baik, maka para da'i mengikuti empat syarat yang dikemukakan oleh Schramm, yakni: pertama, pesan harus diatur begitu rupa sehingga menarik perhatian. Kedua, pesan harus menggunakan lambang-lambang yang sesuai dengan luas lingkup pengalaman (field of experience) serta bingkai referensi (frame of reference) si penerima (mad'u). Ketiga, pesan harus mampu memunculkan kebutuhan pribadi dan menyampaikan saran-saran sebagaimana memenuhi kebutuhan itu. Keempat, pesan harus memberi jalan untuk mengatasi kebutuhan tersebut, yang sesuai dengan situasi dan kondisi mad'u berada (Schramm. 1965).

Dengan mengikuti teori Schramm diatas, jika diperhadapkan dengan materi dakwah yang berlangsung selama ini baik yang disampaikan oleh muballigh (laki-laki) maupun oleh muballighah (perempuan). Materi dakwah yang disampaikan jauh dari kebutuhan masyarakat. Alih-alih dakwah untuk memecahkan persoalan ummat dalam hal ini perempuan. Dakwah Islam 
yang disampaikan justru membuat persoalan perempuan tumbuh subur dengan pemberian pupuk yang bernama interpretasi "teks" keagamaaan yang bias gender.

\section{Wasilah (media dakwah)}

Aktivitas dakwah Islam saat ini tidak cukup dengan menggunakan media-media tradisional, seperti melalui ceramah agama dan pengajian yang masih menggunakan bahasa oral atau komunikasi tutur. Penggunaan media-media komunikasi modern sesuai dengan taraf perkembangan daya pikir manusia harus dimanfaatkan sedemikian rupa, agar dakwah Islam lebih mengena sasaran dan tidak out of date.

Media dakwah pada zaman Rasulullah dan sahabat sangat terbatas, yakni berisar pada dakwah qauliyah bi al-lisan dan dakwah fi'liyah bi al-uswah, ditambah juga dengan media surat yang terbatas. Setelah satu abad kemudian, dakwah menggunakan media, yakni qashash (tukang cerita) dan mu'allafat (karangan tertulis). Kedua macam media ini kemudian berkembang hingga bertahan pada masa kini. Akan tetapi, di era millinium ini, era dimana pengetahuan dan tekhnologi berkembang dengan sangat canggih. Maka dakwah memanfaatkan fasilitas kecanggihan tekhnologi tersebut. Maka, media dakwah kemudian menjadi baru melalui surat kabar, majalah, cerpen, cergam, piringan hitam, kaset, film, radio, televisi, stiker, lukisan, iklan, pementasan di arena pertunjukan, puisi, nyanyian, musik dan media seni lainnya. Kecanggihan tekhnologi sebagai akibat perkembangan zaman dan ilmu pengetahuan mendorong para da'i dalam menjalankan tugasnya (Yafie, 1997).

\section{Thariqah (metode dakwah)}

Metode dakwah adalah cara-cara tertentu yang dilakukan oleh seorang da'i kepada mad'u untuk mencapai suatu tujuan atas dasar hikmah dan kasih sayang (Tasmara, 1997). Al-Qur'an menyebut metode dakwah tersebut dalam QS. An-Nahl:125.

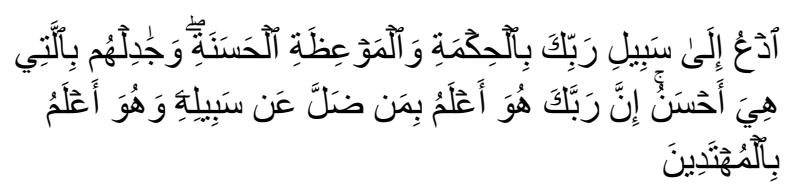

Serulah (manusia) kepada jalan Tuhan-mu dengan hikmah dan pelajaran yang baik dan bantahlah mereka dengan cara yang baik. Sesungguhnya Tuhanmu Dialah yang lebih mengetahui tentang siapa yang tersesat dari jalanNya dan Dialah yang lebih mengetahui orangorang yang mendapat petunjuk.

Inti dari QS. An-Nahl ayat 125 diatas adalah bahwa seruan atau ajakan menuju jalan Tuhan adalah dengan menggunakan metode bi al-hikmah, al-mau'idzah hasanah dan mujadalah bi al-lati hiya ahsan. metode bi al-hikmah adalah dakwah dengan memperhatikan situasi dan kondisi sasaran dakwah dengan menitik beratkan pada kemampuan audiens (mad'u) sehingga ketika mad'u menjalankan ajaran-ajaran Islam, mereka tidak terpaksa tapi penuh dengan kesadaran, atas kemauan sendiri, tidak ada unsur pemaksaan, konflik maupun rasa tertekan. Sedangkan di arti bahasa lain, dakwah "bilhikmah" adalah meletakkan sesuatu sesuai dengan tempatnya, kitalah yang harus berpikir, berusaha, menyusun, dan mengatur cara-cara dengan menyesuaikan dengan kondisi zaman sekarang. Dakwah tersebut dapat dilakukan dengan lisan, tulisan maupun dengan perbuatan asal tidak bertentangan dengan perintah Allah (Umar, 1971). Metode al-mau'idzah hasanah adalah berdakwah dengan cara memberikan nasehat-nasehat yang baik, yaitu petunjukpetunjuk kearah kebaikan dengan bahasa yang baik, dapat diterima, berkenan di hati, menyentuh perasaan, lurus dipikiran, menghindari sikap kasar tidak menyebut kesalahan audiens (mad'u) sehingga mad'u mengikuti isi dakwah dengan rela hati dan atas kesadaran sendiri. Metode mujadalah bi al-lati 
hiya ahsan adalah metode dakwah yang digunakan kepada audiens yang kritis dan memiliki taraf pemikiran yang maju seperti ahli kitab. Metode ini menganjurkan berdebat dengan cara yang baik, sopan santun dan lemah lembut (Amin, 2009).

\section{Atsar (efek dakwah)}

Efek dakwah adalah reaksi dari penyampaian pesan dakwah oleh da'i. Efek ini seringkali disebut dengan feed back (umpan balik) dari proses dakwah. Feed back penting untuk mengetahui seberapa besar pesan yang disampaikan da'i, apakah pesan dakwah dapat diterima dan diterapkan dalam kehidupan seharihari, atau sebaliknya di tolak oleh audiens.

Menurut Rahmat, efek kognitif akan terjadi ketika ada perubahan pada apa yang diketahui, dipahami atau dipersepsi oleh khalayak. Efek yang demikian berkaitan penuh dengan pengetahuain, keterampilan, kepercayaan atau informasi. Efek afektif ini akan timbul apabila terjadi perubahan pada apa yang dirasakan, disenangi, dan dibenci oleh audiens yang meliputi segala yang berhubungan dengan emosi, sikap serta nilai. Sedangkan efek behavioral merujuk pada prilaku nyata yang dapat diamati, yang meliputi pola-pola tindakan, kegiatan atau kebiasaan berprilaku (Rahmat, 1982).

Pada unsur-unsur dakwah diatas, jika dikaitkan dengan konsep teologi feminisme. Seorang da'i dilarang untuk bersifat khitman, yakni menyembunyikan kebenaran yang sudah ia ketahui. Kebenaran yang dimaksud disini adalah kebenaran tentang interpretasi teks baik alQur'an dan hadist yang misoginis, bahwa sebenarnya yang di maksud oleh Allah dan Nabi Muhammad bukanlah demikian. Allah mengutus Nabi Muhammad ke dunia tidak lain dan tidak bukan adalah untuk menyempurnakan akhlak. Kesempurnaan akhlak tersebut dapat terwujud manakala manusia antar manusia yang lain terwujud tatanan masyarakat yang adil gender. Amanah Allah kepada da'i dalam hal ini sangat keras untuk menyampaikan pesan-pesan Tuhan dalam konteks keadilan. Sebagaimana firman Allah.

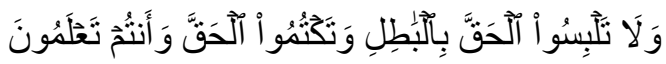

Dan janganlah kamu campur adukkan yang hak dengan yang bathil dan janganlah kamu sembunyikan yang hak itu, sedang kamu mengetahui (QS. Al-Baqarah:42).

\section{Rekonstruksi Materi Dakwah Yang Memarginalkan Perempuan}

Persoalan yang terkait dengan hak asasi perempuan yang melanda banyak perempuan era kini membutuhkan peran seorang da'i yang tidak hanya melakukan ceramah dengan materi-materi yang justru mendukung atau seolah-olah mendorong perempuan-perempuan untuk tidak berkutik. Justru yang dibutuhkan dari seorang da'i kontemporer ini adalah bagaimana menjadi da'ie yang paham tentang tafsir-tafsir dan hadisthadist yang menjunjung keadilan (justice) dan kemanusiaan (humanities).

Menurut Aziz (2011), ada beberapa hal untuk mencapai pola dakwah yang di harapakan diatas. Antara lain: pertama, aspek konten. Materi dakwah yang disampaikan seharusnya mengalami pergeseran, dari yang selalu ukhrawioriented ke materi dakwah yang bersifat sosialkontekstual. Oleh karenanya, seorang da'i dituntut untuk memperluas isu-isu sosial yang terjadi di masyarakat dan mampu menurunkan angka patologi sosial, dalam hal ini seperti trafficking, prostitusi online dan perkawinan anak (chield of marriage). Kedua, aspek pelaku, maksudnya adalah da'i searang tidak berangkat dari dirinya sebagai persoanal, melainkan berangkat dari sebuah institusi lembaga. Dengan institusi ini nantinya dakwah mengaraha kepada gerakan dan perubahan sosial. Ketiga, aspek orientasi, maksudnya adalah seorang da'i 
memiliki orientasi dakwah untuk memperjuangkan hak-hak kaum yang tertindas (mustad'afin). Kaum yang tertindas dalam tulisan ini yang dimaksud adalah kaum perempuan. Dengan adanya orientasi dakwah yang demikian maka seorang da'i tidak hanya menyampaikan pesan-pesan agama lewat ceramah, melainkan juga melakukan bimbingan dan pendampingan, bahkan seorang da'i melakukan advokasi dan pengorganisasian masyarakat terhadap kasus-kasus yang menimpa perempuan.

Pendapat Aziz diatas mengenai pentingnya perseran aspek materi dakwah menjadi penting untuk dikaji mengingat Islam menempatkan perempuan pada posisi yang sama dengan lakilaki. Kesamaan tersebut dapat dilihat pada tiga hal (Fayumi, dkk., 2001): pertama, hakikat kemanusiaan, Islam memberikan sejumlah hak kepada perempuan dalam rangka peningkatan kualitas kemanusiaanya. Hak tersebut antara lain waris (QS. An-Nisa':11), persaksian (QS. AlBaqarah:282), aqiqah (QS. At-Taubah:21) dan lain sebagainya. Kedua, Islam mengajarkan kepada laki-laki dan perempuan, bahwa mereka akan mendapatkan pahala atas amal sholeh yang mereka kerjakan, dan mendapat balasan dosa atas perbuatan buruk yang mereka lakukan. Ketiga, Islam tidak mentolerir adanya perbedaan dan perlakuan tidak adil antar umat manusia, hal itu karena derajad dan status manusia di hadapan Allah itu sama (QS.al-Hujurat:13).

Berangkat dari konsep kesamaan dalam Islam tersebut, maka rekonstruksi terhadap materi dakwah menjadi penting. Adapun materimateri dakwah yang perlu di adakan rekonstuksi dengan berdasar pada interpretasi teks dan hadist sehingga menyebabkan tidak berdaya, kontrol penuh dalam sumber sehingga perempuan tertutup akses kesempatan dalam ekonomi, politik, sosial budaya. Kontrol penuh tersebut lantaran interpretasi teks-teks agama yang misoginis dan menindas perempuan.
Adapun materi dakwah yang perlu di adakan rekosntruksi adalah pada beberapa ayat dan hadist yang selalu dijadikan landasan pijakan dan kutipan da'i dalam ceramahnya. Padahal ayat-ayat tersebut mengindikasikan kekerasan terhadap perempuan. Oleh karenanya, seorang da'i terlebih dahulu sebelum menyampaikan ayat-ayat dan hadist-hadist tentang perempuan, terlebih dahulu untuk mengadakan pembacaan ulang. Pembacaan ulang tersebut dengan cara mengkaji teks ayat dan hadist dengan dasar keadilan dan kesetaraan.

Dalam relasi antara laki-laki dan perempuan, ada sebuah hadist yang terkesan memarginalkan perempuan yaitu sebuah hadist yang berbunyi:

$$
\text { لن يفلح قوم ولو أمر هم امر عة }
$$

"Tidak akan beruntung suatu kaum yang menyerahkan urusan mereka kepada perempuan"

Pembacaan hadist di atas harus dilakukan secara kritis, karena hadist diatas tidak dapat dipertahankan jika diperhadapkan dengan buktibukti sejarah. Bahkan Islam sendiri mengabadikan kesuksesan kepemimpinan perempuan sebagaimana yang digambarkan oleh al-Qur'an melalui kepemimpinan ratu Balqis. Kisah kebesaran ratu Balqis direkam oleh alQur'an dalam surat An-Naml dan surat alAnbiya'.

Ada juga hadist yang seringkali dijadikan rujukan, yakni sebuah hadist yang mengatakan bahwa perempuan tercipta dari tulang rusuk yang bengkok. Dalam sebuah hadist dikatakan dari Abi Hurairoh "Nasehatilah olehmu wanita, sebab itu tercipta dari tulang rusuk yang bengkok, jika kau paksa meluruskannya dengan kekerasan, pasti dia akan patah, dan jika kau biarkan tentu dia akan tetap bengkok. Karena itu nasehatilah olehmu wanita".

Dengan adanya hadist tersebut memberikan kesan bahwa perempuan, dalam hal ini Hawa merupakan ciptaan kedua, sementara 
laki-laki (Adam) adalah ciptaan pertama dan utama. Ketika hadist diatas diuji dan diperbandingkan dengan ayat-ayat al-Qur'an yang berbicara tentang penciptaan manusia, maka tidak satupun ayat yang dapat ditafsirkan sebagai penegasan atau merujuk pada keyakinan bahwa laki-laki diciptakan terlebih dahulu ketimbang perempuan atau perempuan diciptakan dari laki-laki. Bahkan Riffah Hassan, seorang feminis muslim yang gencar mengkritik ayat-ayat dan hadist yang misoginis menemukan bahwa, berdasarkan acuan QS. An-nisa':1, QS. al-A'raf:189 dan QS. az-Zumar: 6 bahwa penafsiran kata penciptaan pertama "nafsin wahidah" justru bersifat perempuan dan bukan laki-laki (Fayumi, dkk., 2001).

Dengan demikian, maka jelaslah bahwa relasi laki-laki dan perempuan merupakan relasi kemitraan yang sejajar. Sebagaimana penegasan Allah dalam al-Qur'an;

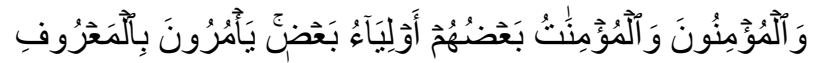

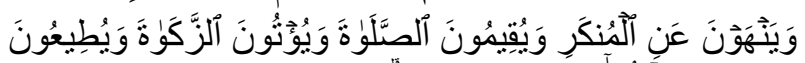

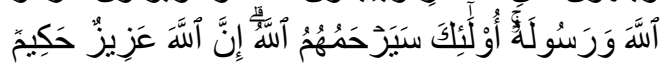

Dan orang-orang yang beriman, lelaki dan perempuan, sebahagian mereka (adalah) menjadi penolong bagi sebahagian yang lain. Mereka menyuruh (mengerjakan) yang ma'ruf, mencegah dari yang munkar, mendirikan shalat, menunaikan zakat dan mereka taat pada Allah dan Rasul-Nya. Mereka itu akan diberi rahmat oleh Allah; sesungguhnya Allah Maha Perkasa lagi Maha Bijaksana. (QS. at-Taubah:71)

Mengacu pada penegasan Allah dalam alQur'an tersebut, maka seharusnya pada da'i ketika akan menyampaikan dakwahnya seharusnya dan selayaknya menggunakan tafsir dan ayat-ayat yang menghargai dan menghormati perempuan dan bukan mengutip ayat-ayat dan hadist yang misoginis. Bahkan dari pembacaan para teolog feminis muslim seperti Amina Wadud, Fatima Mernissi, Riffat Hassan, Nasr Hamid Abu Zaid, Ashgar Ali Engineer dan lain sebagainya, menemukan bahwa hadist-hadist yang menjustifikasi perempuan untuk taat kepada suami, larangan perempuan untuk menjadi pemimpin, perempuan dicipta dari tulang rusuk suami yang bengkok dan lain sebagainya adalah hadist-hadist yang tidak valid, atau dalam bahasa ilmu hadist disebut maudhu', dengan tujuan sebagai sebuah cara untuk memanipulasi agama atas nama kepentingan laki-laki (Muhammad, 2004).

\section{Da' i Sadar Gender: Sebuah Cita-Cita}

Seorang da’i ketika akan menyampaikan materi dakwah yang responsif gender, ia harus memiliki kesadaran gender. Kesadaran gender yang dimaksud adalah kemampuan seseorang dalam hal ini da'i untuk dapat berpikir dan melakukan tindakan proaktif untuk menolak segala bentuk ketimpangan dan kesenjangan gender. Kesadaran gender dalam dakwah ini menjadi penting mengingat dakwah hakikatnya memiliki dua makna (Supena, 2013). Pertama, dakwah sebenarnya adalah membangun standar kualitas hidup. Disini dakwah hakikatnya merupakan suatu upaya mewujudkan masyarakat muslim yang ideal, yaitu masyarakat yang adil, makmur, damai dan sejahtera di bawah limpahan rahmat, karunia dan ampunan Allah (QS. Saba':15). Kedua, dakwah sebagai media transformasi nilai. Transformasi nilai yang dimaksud dalam dakwah ini adalah aktivitas dakwah di rubah dari bentuk komunikasi dogmatik ke dalam bentuk komunikasi intersubjektif yang bersifat emansipatoris. Artinya, seorang da'i (penceramah) dengan mad'u (audiens) harus sama-sama aktif memahami pesan-pesan moral yang disampaikan Tuhan melalui Rasul-Nya, sehingga audiens tidak menerima ceramah agama secara taklid melainkan memahaminya dengan penuh kritik. Demikian pula dengan da'i, ia harus menyampaikan pesan-pesan agama tanpa adanya projudise kepada perempuan. Melainkan menyampaikan pesan-pesan agama dengan 
semangat keadilan (al-'adalah), persamaan (almusawa) dan menghargai harkat dan martabat manusia (al-karomah al-insaniyah).

\section{Daftar Pustaka}

Ahmad (ed.), Amrullah. Dakwah Islam \& Perubahan Sosial, Yogyakarta:PLP2M, 1985.

Alawiyah, Tutty. Membangun Kesadaran Beragama, Jakarta: Yayasan Alawiyah,1992.

Amin, Samsul Munir. Ilmu Dakwah, Jakarta: AMZAH,2009.

Arnold, Thomas W. Sejarah Dakwah Islam, Jakarta: PT. Wijaya, 1981.

Aziz, Ahmad Amir. Pola Dakwah TGH. Muhammad Zainuddin Abdul Majid, Mataram:Larispa,2011.

Dermawan dkk, Andy. Metodologi Ilmu Dakwah, Yogyakarta: LESFI,2002.

Fayumi dkk., Badriyah. Keadilan \& Kesetaraan Gender (Perspektif Islam), Siti Musdah Mulia \& Marzani Anwar (ed.), Jakarta:Tim Pemberdayaan Perempuan Bidang Agama Depag RI, 2001.

Majma, al-Lughah al-'Arabiyah, 1972.

Megawangi, Ratna. Perkembangan Teori Feminisme Masa Kini dan Mendatang Serta Kaitannya Dengan Pemikiran Keislaman, dalam Membincang Feminisme: Diskursus Gender Perspektif Islam, Surabaya:Risalah Gusti,1996.

Muhammad, Husein. Islam Agama Ramah Perempuan:Pembelaan Kyai Pesantren, Nuruzzaman, Jalal, Juri Ardiantoro (ed.) Yogyakarta: LKiS, 2004.
Muhsin, Amina Wadud. Wanita Dalam AlQur'an, Terj. Yaziar R.,Bandung:Pustaka,1994.

Munir dkk,. Metode Dakwah, Jakarta: Kencana, 2006.

PP Rippnas, Kementerian Pemberdayaan Wanita, Jakarta:Memperta 2002-2004.

Priyono, Onny. Pemberdayaan, Konsep daan Implementasi, Jakarta:CSIS, 1996.

Puteh, M. Ja'far. Dakwah \& Globalisasi: Strategi Menghadapi Perubahan Sosial, Yogyakarta: Pustaka Pelajar, 2000.

Rahmat, Jalaluddin. Retorika Modern: Sebuah Kerangka Teori dan Praktek Berpidato, (Bandung: Akademika,1982).

Schramm, Wilbur. The Process and Effects of Mass Communications, Urbana: University of Illinois Press, 1965.

Suhandang, Kustadi. Ilmu Dakwah Perspketif Komunikasi, Bandung:PT Remaja Rosdakarya,2013.

Supena, Ilyas. Filsafat Ilmu Dakwah: Perspektif Filsafat Ilmu Sosial, Yogyakarta: Ombak, 2013.

Tan, Melly G. Perempuan \& Pemberdayaan, Jakarta: Yayasan Obor,1997.

Tasmara, Toto. Komunikasi Dakwah, Jakarta: Gaya Media Pratama,1997.

Umar, Toha Yahya. Ilmu Dakwah, Jakarta: Wijaya, 1971.

Yafie, Ali. Teologi Sosial Telaah Kritis Persoalan Agama dan Kemanusiaan, Yogyakarta:LKPSM, 1997. 